\title{
STRATEGI EVERYONE IS A TEACHER HERE (ETH) UNTUK MENINGKATKAN HASIL BELAJAR PEMAHAMAN KONSEP SAINS FISIKA
}

\author{
Defrizal Hamka ${ }^{1}$, Hadi Purwanto ${ }^{2}$ \\ (Universitas Muhammadiyah Riau) \\ e-mail: 1defrizalhamka@umri.ac.id, ${ }^{2}$ hadipurwanto@umri.ac.id
}

\begin{abstract}
Abstrak
Penelitian ini bertujuan untuk mendeskripsikan hasil belajar keterampilan kognitif siswa melalui penerapa strategi everyone is a teacher here (ETH) pada pembelajaran fisika. Subjek penelitian ini adalah siswa kelas VIII MTs 1 Bangkinang Barat yang berjumlah 28 orang. Instrumen pengumpulan data penelitian ini adalah soal tes hasil belajar keterampilan kognitif. Pengumpulan data pada penelitian ini dilakukan pada akhir proses pembelajaran dengan mengadakan tes keterampilan kognitif. Data dianalisis menggunakan teknik analisa deskriptif yang meliputi daya serap, efektifitas pembelajaran, ketuntasan belajar siswa dan ketuntasan tujuan pembelajaran. Hasil analisa data menunjukkan: daya serap rata-rata siswa adalah $76.01 \%$ dengan kategori baik, ketuntasan belajar siswa secara klasikal adalah $77.78 \%$ dengan kategori tidak tuntas, ketuntasan tujuan pembelajaran secara klasikal adalah $66.7 \%$ dengan kategori tidak tuntas, dan efektifitas pembelajaran $76.01 \%$ dengan kategori cukup efektif. Dengan demikian, penerapan strategi everyone is a teacher here (ETH) cukup efektif digunakan untuk pembelajaran fisika.
\end{abstract}

Kata kunci: Hasil Belajar Kognitf, Strategi Everyone Is a Teacher Here (ETH)

\begin{abstract}
This study aims to describe the learning outcomes of students' cognitive skills through the application of the everyone is a teacher here (ETH) strategy in physics learning. The subjects of this study were students of class VIII MTs 1 Bangkinang Barat, totaling 28 people. The instrument of data collection in this study was a test of cognitive skills learning outcomes. Data collection in this study was carried out at the end of the learning process by conducting cognitive skills tests. The data were analyzed using descriptive analysis techniques which include absorption, learning effectiveness, student learning mastery and learning objectives mastery. The results of data analysis showed: the average absorption of students was $76.01 \%$ in the good category, classical student learning completeness was $77.78 \%$ in the incomplete category, the classical learning objectives mastery was $66.7 \%$ in the incomplete category, and the learning effectiveness was $76.01 \%$ with quite effective category. Thus, the implementation of the everyone is a teacher here (ETH) strategy is quite effective for learning physics.
\end{abstract}

Keywords: cognitive learning outcomes, strategy everyone is a teacher here (ETH).

\section{Pendahuluan}

Dalam proses pembelajaran guru harus memiliki strategi pembelajaran yang tepat terutama dalam berkomunikasi dengan anak didik dan guru juga harus mempunyai kemampuan untuk memilih dan menggunakan metoda dan media sebagai alat bantu mengajar. Guru sebagai pengajar yang memberikan pengtahuan dan keterampilan kepada siswa mempunyai peranan 
sebagai fasilitator, motivator dan sebagai pembimbing dalam mencapai kemajuan dalam belajar (Slameto, 2003).

Salah satu pelajaran IPA yang dipelajari di tingkat Sekolah Menengah Pertama (SMP) adalah fisika. Pelajaran fisika mempelajari gejala-gejala dan interaksi gejala-gejala itu satu sama lain. Fisika adalah bahasa yang digunakan untuk saling berhubungan dan untuk menemukan sifat-sifat yang berlaku secara umum antara berbagai peristiwa alam. Fisika diberikan kepada siswa dengan tujuan membantu siswa agar tertata nalarnya, terbentuk kepribadiannya serta terampil menggunakan fisika dan penalarannya dalam kehidupannya kelak.

Berdasarkan informasi yang diperoleh dari guru fisika kelas VIII MTs N 1 Bangkinang Barat, hasil belajar kognitif fisika siswa belum dapat dikatakan sepenuhnya berhasil. Hal ini terlihat dari rata-rata persentasi ketuntasan dengan skor $62 \%$. Salah satu penyebab tidak tuntasnya pembelajaran di sekolah adalah peran guru di kelas lebih dominan jika dibandingkan siswa. Pembelajaran yang didominasi oleh guru ini membuat siswa menjadi pasif dan kurang berpartisipasi. Siswa hanya mendengar dan mencatat materi yang disampaikan oleh guru. Ketika guru meminta siswa mengajukan pertanyaan tentang hal-hal yang tidak siswa pahami, hanya satu atau dua siswa saja yang bertanya, yang lain hanya diam. Siswa sepertinya juga tidak merasa percaya diri untuk menjawab atau memberikan pertanyaan, baik kepada guru maupun teman sebayanya.

Oleh karana itu perlu diterapkan pembaharuan dalam pembelajaran fisika yang dilakukan oleh guru, sehingga dituntut untuk menggunakan strategi pembelajaran yang tepat, menyenangkan, dapat membantu siswa untuk aktif dan terlibat secara mental serta mendorong siswa mampu membagi pengetahuan yang dimilikinya kepada orang lain, sehingga motivasi dan hasil belajar siswa menjadi lebih baik. Untuk membantu siswa membina konsep atau pengetahuan baru, guru perlu mengetahui struktur kognitif yang mereka miliki. Apabila konsep baru telah disesuaikan dan diserap untuk dijadikan pegangan kuat mereka, barulah bentuk baru tentang sesuatu ilmu pengetahuan dapat dibina (konstruktivisme).

Salah satu metode yang digunakan untuk mengaktifkan siswa adalah dengan metode belajar aktif dengan beberapa tipe strateginya. Metode belajar aktif terdiri atas beberapa tipe strategi, salah satunya strategi tipe Everyone Is a Teacher Here (ETH) (Aprilia, et, al.,2020). ETH berarti setiap siswa dapat bertindak sebagai guru bagi siswa lainnya. Metode belajar aktif didesain untuk menghidupkan suasana kelas, kegiatan belajar yang menyenangkan, dan meningkatkan keterlibatan mental. Strategi tipe ETH adalah salah satu teknik instruksional dari belajar aktif (Active Learning) yang termasuk dalam bagian pembelajaran dengan rekan sebaya (peer teaching). Everyone is a teacher here merupakan sebuah model yang mudah guna memperoleh partisipasi kelas yang besar dan tanggung jawab individu. Model ini memberikan kesempatan pada setiap peserta didik untuk bertindak sebagai "pengajar" terhadap peserta didik lain. Strategi tipe ini merangkum semua manfaat dari peer teaching yang dikemukakan pada alinea sebelumnya. Silberman (2006:183) mengungkapkan prosedur pembelajaran dengan menggunakan tipe Everyone Is a Teacher Here ini adalah: a) Bagikan kartu indeks kepada tiap siswa. b) Kumpulkan kartu. c) Tunjuklah beberapa siswa untuk membacakan kartu yang mereka dapatkan dan memberikan jawabannya. d) Setelah memberikan jawaban, perintahkan siswa lain untuk memberi tambahan atas apa yang dikemukakan oleh siswa yang membacakan kartunya itu.

\section{Metode Penelitian}

Penelitian ini menggunakan pendekatan deskriptif kuantitatif, karena dalam penelitian ini hanya mendeskripsikan penguasaan pemahaman konsep siswa melalui penerapan strategi ETH. Penelitian ini dilakukan di MTs 1 Bangkinang Barat menggunkan teknik pengambilan sampel secara systematic random sampling subjek penelitian adalah siswi kelas VIII yang berjumlah 24 orang. Rancangan penelitian yang digunakan dalam penelitian ini adalah rancangan the one-shot case study. Untuk mendukung terlaksananya pembelajaran pada penelitian ini, maka perangkat pembelajaran yang digunakan pada penelitian ini terdiri dari silabus dan sistem penilaian, RPP dan LKS. 


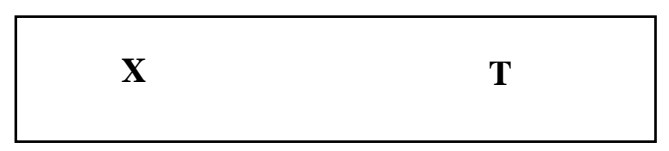

Ket: $\mathrm{X}=$ Perlakuan melalui penerapan pembelajaran aktif strategi ETH

$\mathrm{T}=$ Tes hasil belajar kognitif

Teknik pengumpulan data adalah teknik tes/pemberian tes, dimana data dikumpulkan dengan cara memberikan tes hasil belajar. Instrumen penelitian ini adalah tes hasil belajar berbentuk pilihan ganda dengan melakukan validitas soal, reliabilitas soal, daya pembeda soal dan indeks kesukaran Pemberian tes hasil belajar ini dilakukan setelah pembelajaran melalui penerapan pembelajaran aktif dengan memakai strategi ETH ini berakhir. Teknik analisis data dalam penelitian ini dilakukan dengan menggunakan teknik deskriptif kuantitatif.

\section{Hasil dan Pembahasan}

Berdasarkan hasil analisis data secara deskriptif tentang daya serap, efektivitas pembelajaran, ketuntasan belajar siswa dan ketuntasan tujuan melalui penerapan strategi ETH dalam pembelajaran sains fisika

\section{a. Daya Serap}

Daya serap dimaknai sebagai indeks atau tingkat pemahaman siswa terhadap materi. Dari hasil penelitian diperoleh bahwa rata-rata daya serap untuk setiap rencana pembelajaran berbeda. Hal ini disebabkan karena adanya perbedaan kemampuan siswa dalam menerima dan menyerap materi pelajaran, perbedaan keseriusan siswa dalam melakukan eksperimen dan memperhatikan penjelasan guru serta perbedaan tingkat kesukaran materi.

Rata-rata daya serap siswa yang tertinggi adalah pada RP I yaitu sebesar $81.48 \%$ dengan kategori baik. Hal ini disebabkan karena konsep yang didapat siswa diperkuat dengan percobaan yang mudah dimengerti. Rata-rata daya serap siswa pada RP II rendah yaitu sebesar $71.57 \%$. Ini disebabkan karena siswa kurang menguasai teori. Selain itu, siswa malas untuk menghafal teoritis. Pada rencana pembelajaran III daya serap siswa meningkat yaitu sebesar $73.15 \%$ dengan kategori baik. Pada rencana pembelajaran ini, siswa mulai terbiasa belajar dengan menerapkan strategi ETH. Selain itu materi pada rencana pembelajaran III masih berhubungan dengan materi pada rencana pembelajaran II.

Tabel 1. Daya Serap Siswa

\begin{tabular}{lccc}
\hline No & Uraian Materi Pokok & Daya Serap Rata-rata (\%) & Kategori \\
\hline 1. & RP I & 81.84 & Baik \\
2. & RP II & 71.57 & Baik \\
3. & RP III & 73.15 & Baik \\
\hline & Rata-rata & $\mathbf{7 6 . 0 1}$ & Baik \\
\hline
\end{tabular}




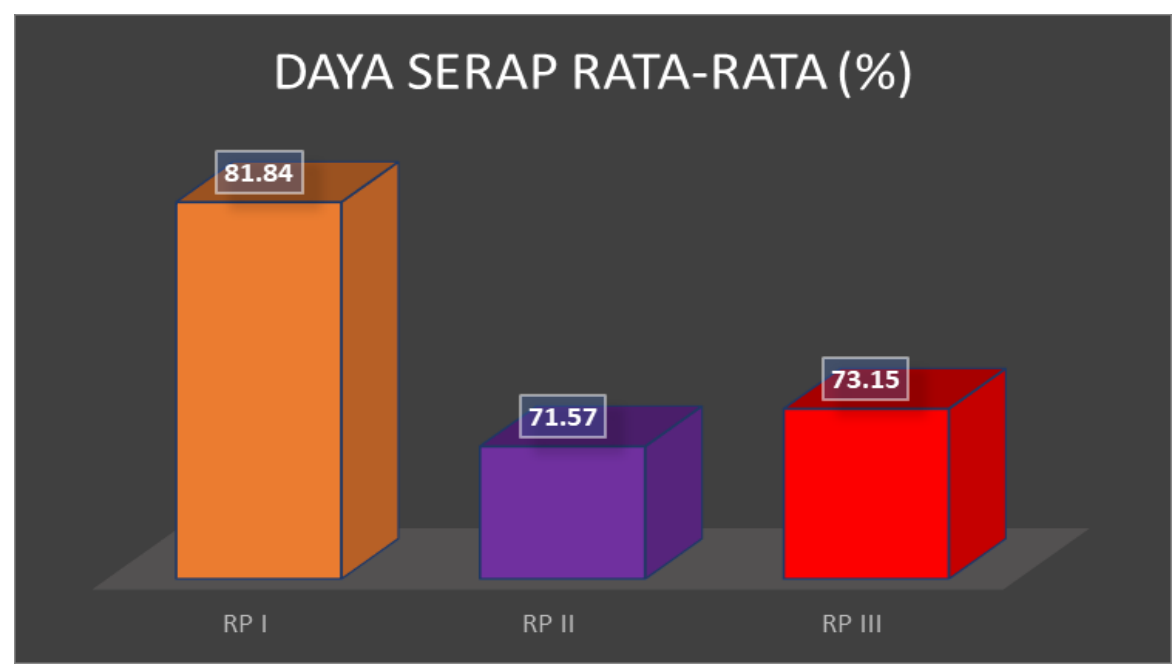

Gambar 1. Daya Serap Siswa

Secara umum rata-rata daya serap siswa adalah $76.01 \%$ dengan kategori baik. Hal ini karena pada pembelajaran dengan menggunakan ETH mengharuskan siswa aktif dalam mengikuti pelajaran. Siswa diharuskan membuat pertanyaan dari materi yang telah dipelajari dan siswa harus menjawab pertanyaan tersebut kemudian mempresentasikannya. Pada strategi ETH ini siswa harus kreatif dalam mengungkapkan ide-idenya serta aktif dalam diskusi kelompoknya.

\section{b. Efektivitas Pembelajaran}

Efektivitas pembelajaran merupakan manjur tidaknya metode yang diterapkan dalam pembelajaran. Efektivitas pembelajaran ditentukan oleh daya serap yang diperoleh siswa setelah proses pembelajaran selesai. Melalui penerapan strategi ETH, efektifitas pembelajaran pada rencana pembelajaran II dan III cukup efektif.

Tabel 2. Efektivitas Pembelajaran

\begin{tabular}{cccc}
\hline No & Uraian Materi Pokok & Daya Serap Rata-rata $(\boldsymbol{\%})$ & Kategori \\
\hline 1. & RP I & 81.48 & Efektif \\
2. & RP II & 73.15 & Cukup Efektif \\
3. & RP III & 71.57 & Cukup Efektif \\
\hline & Rata-rata & $\mathbf{7 6 . 0 1}$ & Cukup Efektif \\
\hline
\end{tabular}




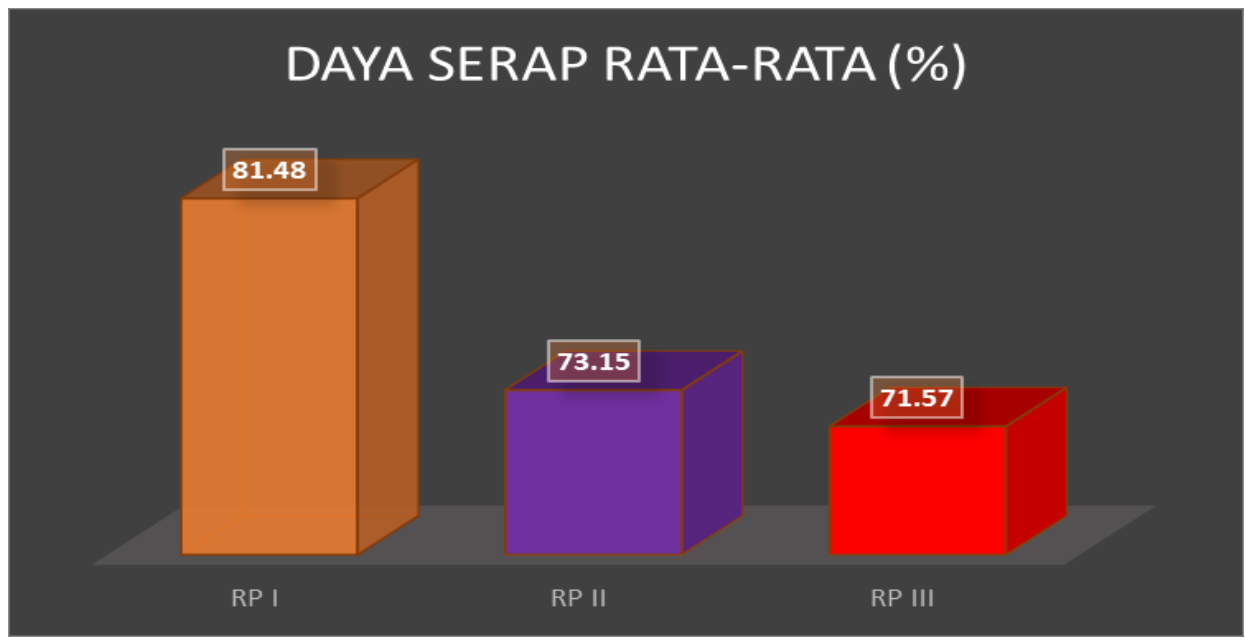

Gambar 2. Efektivitas Pembelajaran

Secara keseluruhan efektifitas pembelajaran dikategorikan cukup efektif dengan persentase rata-rata $76.01 \%$. Jika dilihat selama proses pembelajaran berlangsung, siswa terlihat aktif dan terlibat secara keseluruhan dalam kegiatan pembelajaran. Efektifitas pembelajaran masih dikategorikan cukup disebabkan guru kurang bisa memanfaatkan waktu yang tersedia.

\section{c. Ketuntasan Belajar Siswa}

Ketuntasan belajar adalah pencapaian taraf penguasaan minimal yang ditetapkan bagi setiap unit bahan pelajaran, baik secara peorangan maupun kelompok. Ketuntasan individu dinyatakan telah terpenuhi jika siswa telah mencapai taraf penguasaan $\geq 75 \%$ yang ditetapkan untuk masing masing materi pokok yang dipelajari siswa. Dari tiga rencana pembelajaran, rencana pembelajaran pertama dinyatakan tuntas dengan persentase $81.48 \%$ dan rencana pembelajaran II dinyatakan tidak tuntas dengan persentase $70,35 \%$ begitu juga dengan rencana pembelajaran III dinyatakan tidak tuntas. Hal ini disebabkan karena siswa kurang memahami konsep. Selain itu, kondisi siswa juga mempengaruhi ketuntasan belajar. Siswi MTs 1 Bangkinang Barat mempunyai banyak mata pelajaran, selain mata pelajaran wajib juga ada mata pelajaran tambahan (mata pelajaran pondok). Ketuntasan belajar melalui penerapan strategi ETH secara klasikal dinyatakan tidak tuntas.

Tabel 3. Ketuntasan Belajar Siswa

\begin{tabular}{lcccc}
\hline No & $\begin{array}{c}\text { Uraian Materi } \\
\text { Pokok }\end{array}$ & $\begin{array}{c}\text { Jumlah Siswa } \\
\text { Yang Tuntas }\end{array}$ & Ketuntasan $(\%)$ & Kategori \\
\hline 1. & RP I & 23 & 85.19 & Tuntas \\
2. & RP II & 18 & 66.67 & Tidak Tuntas \\
3. & RP III & 18 & 66.67 & Tidak Tuntas \\
\hline & Rata-rata & $\mathbf{2 1}$ & $\mathbf{7 7 . 7 8}$ & Tidak Tuntas \\
\hline
\end{tabular}

Berdasarkan Debdikbud (1994) bahwa ketuntasan belajar klasikal dinyatakan tuntas jika $\geq 85 \%$ siswa telah menguasai materi pelajaran. Pada pembelajaran dengan menerapkan strategi ETH diperoleh ketuntasan belajar siswa secara klasikal adalah $77.78 \%$. Berarti ketuntasan belajar secara klasikal dinyatakan tidak tuntas. Hal ini karena penerapan strategi ETH masih baru bagi siswa. Siswa yang sebelumnya terbiasa dengan pengajaran yang bepusat pada guru ketika diharuskan membuat pertanyaan dan menjawab pertanyaan (aktif dalam berpikir) menjadi bingung dan perlu bimbingan lebih dari guru sehingga membutuhkan waktu yang tidak singkat. 


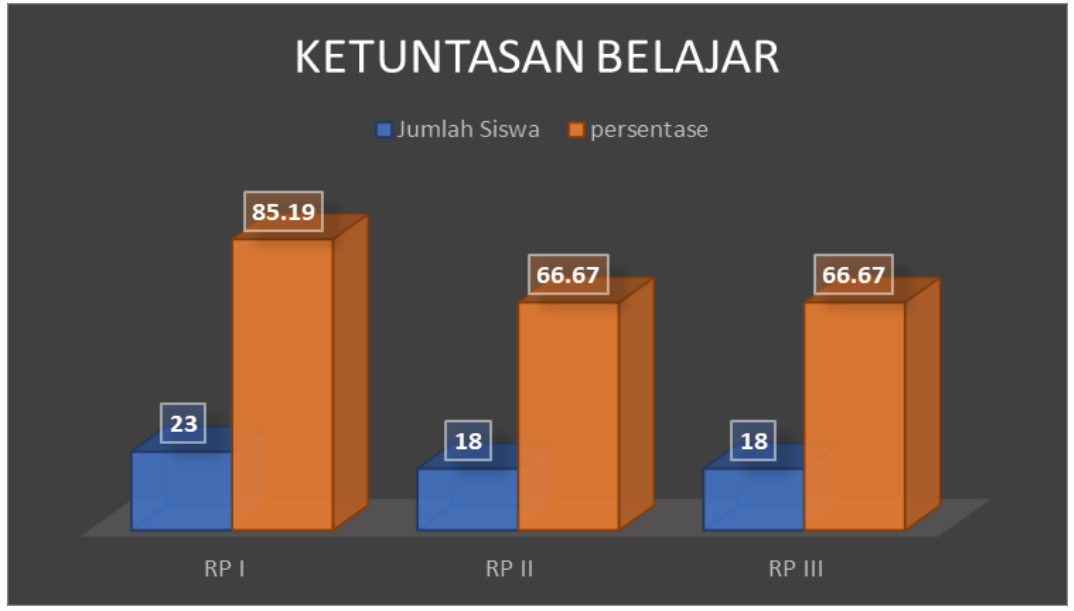

Gambar 3. Garfik Ketuntasan belajar

Dari nilai rata-rata tes akhir tesebut jelas terlihat bahwa adanya peningkatan hasil belajar siswa kelas eksperimen dibandingkan dengan kelas kontrol. Hal ini juga sesuai dengan penelitian Misnar (2011) yang mengatakan bahwa "dalam proses pembelajaran menggunakan strategi belajar aktif tipe ETH siswa dituntut untuk berfikir kritis, menemukan suatu masalah dan mencari pemecahan disetiap permasalahan yang mereka temukan". Menurut Bruner (1973) dalam Lufri (2007:14) "belajar melibatkan tiga proses yang berlangsung hampir bersamaan, yaitu: (1) memperoleh informasi baru, (2) transformasi informasi, dan (3) menguji relevansi dan ketepatan pengetahuan". Dari uraian di atas maka dapat disimpulkan bahwa strategi pembelajaran aktif tipe ETH memberikan dampak terhadap hasil belajar siswa

\section{Kesimpulan}

Berdasarkan hasil pembahasan diperoleh bahwa rata-rata daya serap siswa dengan penerapan strategi everyone is a teacher here (ETH) adalah baik, sedangkan efektifitas pembelajaran dikategorikan cukup efektif. Ketuntasan belajar siswa secara klasikal dinyatakan tidak tuntas dengan persentase $77.78 \%$ dan ketuntasan tujuan pembelajaran secara klasikal dinyatakan tidak tuntas dengan persentase $66.7 \%$. Penerapan strategi everyone is a teacher here (ETH) dapat dijadikan sebagai salah satu alternatif yang dapat diterapkan dalam proses pembelajaran fisika. Sehingga dapat meningkatkan hasil belajar kognitif siswa. Penerapan strategi ETH hendaklah dilakukan sesuai dengan tahap-tahap yang ada. Guru harus benar-benar pandai membagi waktu sehingga semua tahap-tahapnya terlaksana. Guru sebaiknya lebih memberikan penekanan konsep pada materi yang diajarkan, dan lebih banyak memberikan latihan-latihan soal kepada siswa. Disarankan bagi peneliti selanjutnya dapat mencoba pada bidang ilmu yang berbeda untuk meningkatkan mutu pendidikan dimasa yang akan datang.

\section{Daftar Pustaka}

[1] A. Atmadi dan Y. Setyaningsih, Transformasi Pendidikan Memasuki Millenium Ketiga, (Yogyakarta: Kanisius, 2000), hlm. 7

[2] Aprilia, W, Ansori, Y.Z. Penggunaan Model Everyone is A Teacher Here dalam Meningkatkan Hasil Belajar Siswa. Seminar Nasional Pendidikan, FKIP UNMA 2020. 270-277.

[2] Candra, O., Yanto, D.T.P. Strategi Pembelajaran Aktif "Everyone Is A Teacher Here" Guna Meningkatkan Hasil Belajar Siswa. Jurnal PAJAR (Pendidikan dan Pengajaran). (2020). 4 (3), 616-623. 
[3] Halidin. Pengaruh Strategi Pembelajaran Everyone is A Teacher Here Terhadap Hasil Belajar Matematika. Aksioma. (2020). 9 (2), 348-357.

[4] Lufri. Kiat Memahami Metodologi dan Melakukan Penelitian. UNP Pres: Padang.( 2007) , dkk. Strategi Pembelajaran Biologi. UNP: Padang. (2007)

[5] Misnar. Perbandingan Hasil Belajar Biologi Siswa dengan Menggunakan Strategi Everyone Is A Teacher Here (ETH) dan Strategi Listener Team Pada Siswa Kelas VIII SMPN 03 Koto Baru. Skripsi STKIP PGRI: (2011). Padang.

[6] Ramayani, Sitompul, D.N. Pengaruh Strategi Pembelajaran Everyone is A Teacher Here Terhadap Hasil Belajar Akuntansi Siswa Kelas XI SMK Pab 2 Helvetia. Liabilities (Jurnal Pendidikan Akuntansi). (2020). 3 (2), 96-107.

[7] Silberman, M.L. Active Learning 101 Cara Bealajar Siswa Aktif. Bandung: Nuansa. (2006).

[8] Slameto. Belajar dan Faktor-faktor yang Mempengaruhinya. Jakarta: Rineka Cipta. (2003).

[9] Sudjana, N., Arifi, D. Cara Belajar Siswa Aktif dalam Proses Belajar Mengajar. Bandung: Sinar Baru. (1988).

[10] Syaiful, S., Aprillya, S., Anggraeni, E. Pengaruh Strategi Pembelajaran Everyone is a Teacher Here (ETH) Ditinjau dari Gaya Kognitif Terhadap PemahamanKonsep Matematika. Jurnal Gantang. (2020). 5 (1), 51-59.

[11] Zaini, H., Munthe, B., Aryani, S.A. Strategi Pembelajaran Aktif. Yogyakarta: Pustaka Insan Madani. (2008). 